\title{
Impact of Malaysian Continental Drift on the Genetic Diversity of Horseshoe Crab Inferred through mtDNA Sequence Analysis
}

\author{
M. Rozihan (Corresponding author) \\ Department of Aquaculture, Faculty of Agriculture \\ Universiti Putra Malaysia, UPM 43400, Serdang, Selangor, Malaysia \\ E-mail: rzihan@hotmail.com \\ E. Ismail \\ School of Bioscience and Biotechnology \\ Faculty of Science and Technology \\ Universiti Kebangsaan Malaysia \\ UKM Bangi 43600, Selangor D.E. Malaysia \\ E-mail: bajphd@yahoo.co.in
}

Received: August 12, 2011

Accepted: September 1, 2011

Published: January 1, 2012

doi:10.5539/ijb.v4n1p104

URL: http://dx.doi.org/10.5539/ijb.v4n1p104

\begin{abstract}
An attempt was made to examine the influence of Malaysian continental drift on the genetic and haplotype diversity of Malaysian horseshoe crab (Tachypleus gigas [Muller, 1785]) distributed along the east coast of Peninsular Malaysia and distant Borneo Island. Mitochondrial DNA (AT rich region $=369 \mathrm{bp}$ ) analysis showed that T. gigas has higher haplotype diversity in peninsular Malaysia compared to east Malaysian (Sarawak) samples. Highest haplotype diversity $(h \pm S D)$ was observed among the Terengganu samples $(0.813 \pm 0.071)$ followed by Pahang samples $(0.813 \pm 0.065)$. There were no difference in nucleotide diversity $(\pi)$ noted in east cost of Peninsular Malaysian (PM) samples. Overall haplotype $(h \pm S D)$ and nucleotide $(\pi \pm S D)$ diversity of $T$. gigas in PM samples including Sarawak was $0.827 \pm 0.051$ and $0.0078 \pm 0.0014$ respectively. A total of 6 unique haplotypes were recorded of which 2, 2 and 1 were unique to Terengganu, Sarawak and Pahang samples respectively. Pair wise haplotype frequency $\left(\mathrm{F}_{S T}\right)$ value was not statistically significant $(\mathrm{P}>0.05)$ for all the groups indicating the limited gene flow among the population. In addition phylogenetic scrutiny visibly clustered $T$. gigas samples from $T$. tridentatus samples representing sound phylogenetic signals in mtDNA AT rich region. The findings from this study have important implications for proper management and conservation of horseshoe crab in Malaysia.
\end{abstract}

Keywords: Haplotype diversity, Nucleotide diversity, mtDNA AT rich region, Tachypleus gigas, Genetic conservation

\section{Introduction}

Horseshoe crabs are a unique group of animals remarkably retaining their genetic makeup virtually unaffected over millions of years (Kamaruzzaman et al., 2011; John et al., 2010a). They are marine chelicerate arthropod belong to the class merostomata. Despite their name, they are more closely related to spiders, ticks and scorpions than to crabs (kamaruzzaman et al., 2011). There are four extant species of horseshoe crabs, Tachypleus tridentatus, Tachypleus gigas, Carcinoscorpius rotundicauda and Limulus polyphemus. Demographic data showed their global distributory pattern where Atlantic horseshoe crab (L. polyphemus) most commonly found in Gulf of Mexico, Southeast Asian horseshoe crab (T. gigas) found in the shores of the bay of Bengal particularly along the coast of Orissa (India) to Indo-China, North Vietnam, Borneo and Celepes), T. tridentatus (Northern shores of Japan up to South Vietnam and along the Western islands of the Philippines) and (Mangrove horseshoe crab) C. rotundicauda (Northern shores of the bay of Bengal to the Southern coast of the Philippines) where they inhabit in the continental shelf region within $47.7 \mathrm{~km}$ upto $312 \mathrm{~km}$ (Elizabeth, 2001; Chatterji et al., 1992). Out of 
four extant species of horseshoe crabs, 3 are inhabiting Malaysian coastal waters while the distribution of $T$. tridentatus is restricted to East Malaysian coasts (Sabah and Sarawak regions) (John et al., 2010).

In recent decades, various molecular tools have been widely used in variety of generic diversity studies, population structure prediction including their phylogeny and phylogeographic analysis (Rozihan and Ismail, 2011). Nowadays, phylogeography has become a powerful field of research revealing the principles and processes determining the geographic distribution of genealogical lineages, within and among closely related species (Avise, 2000). The main goal of this 'comparative phylogeography' has been to search for concordant geographical distribution among lineages within different species, which would indicate the influence of common historical factors. Recent comparative phylogeographic studies have found that vicariance phenomena has major role in structuring species assemblages and their genetic diversity in geographically distinct population of same species (Arbogast and Kenagy, 2001). It has been widely argued that the restricted population of $T$. tridentatus in East Malaysia might probably due to the continental drift that took place over 1000 years back (Jeannette and Ridder-Numan, 1996; Whitten et al., 1996). Recently Ward et al., (2005), suggested that molecular genetic analysis is a powerful tool for investigating genetic differentiation within and among the population of species which would eventually give genetic history of the population under study. Many studies were conducted to evaluate the genetic break between the northern and southern populations of American horseshoe crabs (L.polyphemus) along the Florida state by using allozyme (Giribet et al., 2001), mitochondrial DNA restriction fragment length polymorphism (RFLP) analysis (Pierce et al., 2000), and microsatellite (King and Eackles, 2004). However, related studies on their conspecific in Malaysian coast are still scanty except in West coast (Rozihan and Ismail, 2011).

The mtDNA AT rich region is a highly variable, non coding region that is useful for phylogeographical studies and population genetic surveys, although the high AT content poses technical and analytical problems (Vila and Bjorklund, 2004). Study had been carried out to predict the population structure of tri spine horseshoe crab ( $T$. tridentatus) using mtDNA AT rich region as a marker gene in Taiwan (Yang et al., 2007) and on T. gigas along the west coast of Malaysia (Rozihan and Ismail, 2011). Present work is the first attempt to evaluate the genetic diversity of $T$. gigas distributed along the East coast of peninsular Malaysia together with east Malaysian sample.

\section{Materials and Methods}

\subsection{Study site and sample collection}

A total of 3 sampling sites were located ( 2 sites from peninsular Malaysia and 1 from east Malaysia [Sarawak]) and 30 Tachypleus gigas samples were collected from the nesting beaches (Terengganu = 14; Pahang $=10$ and Sarawak =6) during 2008 (Figure 1 \& Table 1). Samples were identified, weighed, sexed and morphometric, meristic characteristics were measured. A piece of walking leg was excised from each sample using sterilized scissors and the internal soft tissue was preserved in 95\% ethanol (John et al., 2010). All the animals were released back into the ocean in live condition to make sure their sustainable fishery.

\subsection{Wet lab work}

DNA isolation was performed by following the published method (John et al., 2010). The complete AT rich region of mtDNA was amplified by a pair of primers, Hb-trna (5'-GAGCCCAATAGCTTAAATTAGCTTA-3') and $\mathrm{Hb}-12 \mathrm{~S}$ (5'- GTCTAACCGCGGTAGCTGGCAC-3') (Yang et al., 2007). Amplification reaction was conducted in $50 \mu \mathrm{l}$ buffer supplied with the enzyme and under the conditions recommended by the manufacturer (Invitrogen, Germany). Each $50 \mu \mathrm{l}$ volume contained $50 \mathrm{mM} \mathrm{KCl,} 10 \mathrm{mM}$ Tris (pH 9), $3 \mathrm{mM} \mathrm{MgCl}_{2} 0.2 \mathrm{mM}$ each dNTP, $0.04 \mathrm{mM}$ each primer, 0.033 units of Tag polymerase, $1 \mu \mathrm{l}$ DMSO and $50 \mathrm{ng}$ of mtDNA. The thermocyclic conditions for PCR included the initial denaturation at $94^{\circ} \mathrm{C}$ for $1 \mathrm{~min}$, five cycles of $94^{\circ} \mathrm{C}$ for 30 sec, annealing at $45^{\circ} \mathrm{C}$ for $40 \mathrm{sec}$, and extension at $72^{\circ} \mathrm{C}$ for $1 \mathrm{~min}$, with a final extension at $72^{\circ} \mathrm{C}$ for $10 \mathrm{~min}$, followed by indefinite hold at $4^{\circ} \mathrm{C}$. Following PCR, about $10 \mu \mathrm{l}$ of PCR product with $2 \mu \mathrm{l}$ of bromo thymol blue were added to $2 \%$ agarose gel, prepared with $2.5 \mu \mathrm{l}$ of $1 \%$ Ethidium Bromide and electrophorized at $90 \mathrm{~V}$ until the dye moved for $6 \mathrm{~cm}$ in the gel. The gel was moved to gel doc system for viewing the amplicons with the aid of UV trans-illuminator. Final PCR product was sequenced using ABI 3730xl sequencer and obtained chromatogram was edited via ABI sequence scanner software $1.0 \mathrm{v}$.

\subsection{Data analysis and software prediction}

All data analyses were analyzed using Arlequin 3.0v for a Macintosh platform (Excoffier et al., 2005). Unique haplotypes and all transitions and transversions were counted. Haplotype diversity $(h)$, nucleotide diversity (Shimatani, 1999), and their standard errors were calculated. Pairwise F- statistics $\left(\mathrm{F}_{S T}\right)$ were calculated as genetic distances based on pair wise differences between populations using Dna SP software 4.50.3v (Rozas et al., 2003). 
An indirect estimate of gene flow was calculated based on the equation $N_{e} m=0.5 \times\left[\left(1 / \mathrm{F}_{\mathrm{ST}}\right)-1\right]$ where $N_{e}$ is the effective number of females and $m$ is the migration rate. Percentage of AT was calculated using Bio edit software (Hall, 1999) and Transition:Transversion (Ti:Tv) ratio was calculated using MEGA 4.0 (Tamura et al., 2007).

\section{Results and Discussion}

We identified 14 haplotypes among the T.gigas samples from East coast of peninsular Malaysia (PM) including Sarawak. Among these haplotypes 2 (TG2, 4), 2 (TG8, 9) and 1 (TG3) were unique to Terengganu, Sarawak and Pahang samples respectively (Table 2). The complete data matrix comprised of these 14 haplotypes as well as with T.tridentatus sample as an out group clearly clustered T.tridentatus in separate branch (Figure 2) indicating high phylogenetic cues in mtDNA AT rich strand. The observed mean transition to transversion ratio in the mtDNA AT rich strand was 2.6. The observed mean AT content in the controlled region (mtDNA AT rich region) was $86.03 \%$ (Table 3). Haplotype diversity was comparatively higher in PM samples than east Malaysian $T$. gigas. Greater haplotype diversity was noted in Terengganu horseshoe crab populations $(0.867 \pm 0.071)$ followed by Pahang samples $(0.813 \pm 0.065)$ and Sarawak samples $(0.8 \pm 0.172)$. There were no changes in the nucleotide diversity observed between the PM samples. These two observation clearly indicated the restricted gene flow together with higher polymorphic cites in the mitochondrial genome within the PM crab population in contrast to PM and East Malaysian (EM) samples. Similar observation was noted in horseshoe crab population from Malaysian west coast samples where the geographically closer population had restricted gene flow (Rozihan and Ismail, 2011; Smith et al., 2009). Yang et al., (2007) has observed that T. tridentatus population from closer geographical area of Taiwan coastal waters showed almost similar level of nucleotide diversity which eventually led to the restricted gene flow among the population. The lowest nucleotide diversity in Sarawak crab samples might probably due to 1 . Their recent colonization in east Malaysia, 2. The continental drift that separated the PM and EM might have carried along a patchy population of $T$. gigas towards the EM together with the complete shifting of T. tridentatus population from East coast of PM. Similar results were observed in previous study (Hewitt, 1999). Avise, (2000) also proposed that a rapid expansion from refugial populations involves serial bottlenecks with progressive loss of allelic diversity resulting in less genetic diversity among populations living in the more recently colonized places.

\subsection{Gene flow and migratory rate}

The fixation index ( $F_{\mathrm{ST}}$ value) between Pahang vs Terengganu samples were lower $(0.038)$ indicating restricted gene flow between these populations. This observation was also proved by migratory rate per generation between populations $\left(N_{\mathrm{e}} \mathrm{m}\right)$ which revealed the higher migratory rate between Pahang vs Terengganu samples (12.658) (Table 4). This analysis clearly proved the greater migration of horseshoe crab samples along the east coast of peninsular Malaysia while the migration between PM to EM is highly restricted. Similar observations were also recorded in other aquatic organisms (Wong et al., 2011; Van der Kuyl et al., 2005).

\section{Conclusion}

Present study proved the restricted geographical gene flow among the $T$. gigas population along the east coast of peninsular Malaysia. The influence of Malaysian continental drift which separated peninsular Malaysia from East Malaysia (Borneo) had apparent effect on the dispersal of $T$. gigas towards Sarawak region. However, additional molecular data together with increased sample size would pave a way in exploring the dispersal pattern of horseshoe crab along the Malaysian coast line. This genetic information of the local populations could be used to enact different conservation strategies for their sustainable fishery along the Malaysian coast line.

\section{Acknowledgement}

Author wish to extend his sincere gratitude to ministry of Higher Education Malaysia who funded this project under Fundamental Research Grant Scheme (FRGS) (Project Reference Number: 02-10-07-307FR).

\section{References}

Chatterji, A., Mishra, J., \& Parulekar, A. (1992). Feeding behaviour and food selection in the horseshoe crab, Tachypleus gigas (Müller). Hydrobiologia, 246(1), 41-48. http://dx.doi.org/10.1007/BF00005621

Elizabeth, A. W. (2001). A horseshoe crab (Limulus polyphemus) demographic study. Master of Science, Virginia Tech, United States.

Excoffier, L., Laval, G., \& Schneider, S. (2005). Arlequin ver. 3.0: An integrated software package for population genetics data analysis. Evolutionary Bioinformatics. [Online]: Available: http://www.la-press.com/arlequin-version-30-an-integrated-software-package-for-population-gene-article-a188 
Hall, T. A. (1999). BioEdit: a user-friendly biological sequence alignment editor and analysis program for Windows 95/98/NT. Nucleic Acids Symposium Series, 41, 95-98.

Hewitt, G. M. (1999). Post-glacial re-colonization of European biota. Biological Journal of the Linnean Society, 68(1-2), 87-112. http://dx.doi.org/10.1111/j.1095-8312.1999.tb01160.x

Jeannette, W. A., \& Ridder-Numan. (1996). Historical biogeography of the Southeast Asian genus Spatholobus (Legum.-Papilionoideae) and its allies. Blumea. Supplement, 10, 1-144.

John, A., Prasanna kuma, C., Lyla, P. S., Khan, S. A., \& Jalal, K. C. A. (2010). DNA barcoding of Lates calcarifer (Bloch, 1970). Research Journal of Biological Sciecne, 5, 414-419. http://dx.doi.org/10.3923/rjbsci.2010.414.419

John, B. A., Jalal, K. C. A., Kamaruzzaman, Y. B., \& Zaleha, K. (2010a). Mechanism in the clot formation of horseshoe crab blood during bacterial endotoxin invasion. Journal of Applied Sciences, 10, 1930-1936. Kamaruzzaman, B. Y., Akbar John, B., Zaleha, K., \& Jalal, K. C. A. (2011). Molecular phylogeny of horseshoe crab. Asian Journal of Biotechnology, 3, 302-309.

Kamaruzzaman, B. Y., Akbar John, B., Zaleha K., \& Jalal, K. C. A. (2011). Molecular phylogeny of horseshoe crab. Asian Journal of Biotechnology, 3, 302-309. http://dx.doi.org/10.3923/ajbkr.2011.302.309

King, T. L., \& Eackles, M. S. (2004). Microsatellite DNA markers for the study of horseshoe crab (Limulus polyphemus) population structure. Molecular Ecology Notes, 4(3), 394-396. http://dx.doi.org/10.1111/j.1471-8286.2004.00663.x

Pierce, J. C., Tan, G., \& Gaffney, P. M. (2000). Delaware Bay and Chesapeake Bay Populations of the Horseshoe Crab Limulus polyphemus Are Genetically Distinct. Estuaries, 23(5), 690-698. http://dx.doi.org/10.2307/1352895

Rozas, J., Sánchez-DelBarrio, J. C., Messeguer, X. \& Rozas, R. (2003). DnaSP, DNA polymorphism analyses by the coalescent and other methods. Bioinformatics, 19, 2496-2497. http://dx.doi.org/10.1093/bioinformatics/btg359

Rozihan, M., \& Ismail, E. (2011). Genetic Structure and Haplotype Diversity of Tachypleus gigas Population along the West Coast of Peninsular Malaysia-Inferred through mtDNA AT Rich Region Sequence Analysis. Biotechnology.

Shimatani, K. (1999). The Appearance of a Different DNA Sequence May Decrease Nucleotide Diversity. Journal of Molecular Evolution, 49(6), 810-813. http://dx.doi.org/10.1007/PL00006604

Smith, D., Botton, M. L., Tanacredi, J. T., Nishida, S., \& Koike, H. (2009). Genetic Structure of Japanese Populations of Tachypleus tridentatus by mtDNA AT-Rich Region Sequence Analysis. In Biology and Conservation of Horseshoe Crabs. pp.183-196. Springer US.

Tamura, K. J., Dudley, M., Nei, \& Kumar, S. (2007). MEGA4: Molecular Evolutionary Genetics Analysis (MEGA) software version 4.0. Molecular Biology and Evolution. 24, 1596-1599. http://dx.doi.org/10.1093/molbev/msm092

Van der Kuyl, A., Ballasina, D., \& Zorgdrager, F. (2005). Mitochondrial haplotype diversity in the tortoise species Testudo graeca from North Africa and the Middle East. BMC Evolutionary Biology, 5(1), 29. http://dx.doi.org/10.1186/1471-2148-5-29

Vila, M., \& Bjorklund, M. (2004). The utility of the neglected mitochondrial control region for evolutionary studies in Lepidoptera (insecta). Journal of Molecular Evolution, 58, 280-290. http://dx.doi.org/10.1007/s00239-003-2550-2

Ward, R. D., Zemlak, T. S., Innes, B. H., Last, P. R., \& Hebert, P. D. N. (2005). DNA barcoding Australia's fish species. Philosophical Transactions of the Royal Society B Biological Science 360, 1847-1857.

Whitten, T., Soeriaatmadja, R. E. \& Afiff, S. A. (1996). The ecology of Java and Bali. Periplus Editions.

Wong, Y. T., Meier, R., \& Tan, K. S. (2011). High haplotype variability in established Asian populations of the invasive Caribbean bivalve Mytilopsis sallei (Dreissenidae). Biological Invasions. pp. 341-348. http://dx.doi.org/10.1007/s10530-010-9825-5

Yang, M. C., Chen, C. A., Hsieh, H. L., \& Chen, C. P. (2007). Population Subdivision of the Tri-Spine Horseshoe Crab, Tachypleus tridentatus, in Taiwan Strait. Zoological Science, 24(3), 219-224. http://dx.doi.org/10.2108/zsj.24.219 
Table 1. Detailed information of the sampling location and geographical information (Note: EPM: East Peninsular Malaysia, EM: East Malaysia [Sarawak])

\begin{tabular}{|c|c|c|c|c|}
\hline Geographical region & Sampling site & Sample ID & \multicolumn{2}{|c|}{ Site locations (GPS reading) } \\
\hline EPM & Pahang & PAH & $\mathrm{N} 03^{0} 31.988^{\prime}$ & E $103^{0} 27.534^{\prime}$ \\
\hline EPM & Terengganu & TER & $\mathrm{N} 05^{0} 41.000^{\prime}$ & E $102^{0} 42.594^{\prime}$ \\
\hline EM & Sarawak & SAR & $\mathrm{N} 01^{0} 38.944^{\prime}$ & E $110^{\circ} 28.508^{\prime}$ \\
\hline
\end{tabular}

Table 2. Variable sites found in a fragment of AT-rich region of Tachypleus gigas and their distribution in the population.

\begin{tabular}{|c|c|c|c|c|c|c|c|c|c|c|c|c|c|c|c|c|c|c|c|c|}
\hline \multirow{2}{*}{ 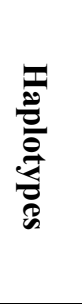 } & \multicolumn{16}{|c|}{ Nucleotide positions } & \multicolumn{3}{|c|}{ Populations } & \multirow{2}{*}{ Total } \\
\hline & $\begin{array}{l}6 \\
6\end{array}$ & $\begin{array}{l}7 \\
6\end{array}$ & $\begin{array}{l}9 \\
6\end{array}$ & $\begin{array}{l}1 \\
0 \\
1\end{array}$ & $\begin{array}{l}1 \\
2 \\
2\end{array}$ & $\begin{array}{l}1 \\
3 \\
1\end{array}$ & $\begin{array}{l}1 \\
3 \\
8\end{array}$ & $\begin{array}{l}1 \\
5 \\
1\end{array}$ & $\begin{array}{l}1 \\
5 \\
4\end{array}$ & $\begin{array}{l}1 \\
8 \\
2\end{array}$ & $\begin{array}{l}1 \\
9 \\
4\end{array}$ & $\begin{array}{l}1 \\
9 \\
6\end{array}$ & $\begin{array}{l}2 \\
0 \\
9\end{array}$ & $\begin{array}{l}2 \\
8 \\
6\end{array}$ & $\begin{array}{l}2 \\
9 \\
9\end{array}$ & 8 & PAH & TER & SAR & \\
\hline TG1 & G & G & $\mathrm{T}$ & A & A & $\mathrm{T}$ & $\mathrm{C}$ & $\mathrm{C}$ & A & $\mathrm{T}$ & A & A & G & A & $\mathrm{T}$ & $\mathrm{C}$ & 5 & 2 & 1 & 8 \\
\hline TG2 & $*$ & A & $*$ & $*$ & $*$ & $*$ & $*$ & $*$ & $*$ & $*$ & $*$ & $*$ & $*$ & $*$ & $*$ & $\mathrm{~T}$ & & 1 & & 1 \\
\hline TG3 & $*$ & A & $\mathrm{C}$ & $*$ & $*$ & * & $*$ & * & * & $*$ & G & $*$ & $*$ & G & $*$ & * & 1 & & & 1 \\
\hline TG4 & A & $*$ & $*$ & G & $*$ & $*$ & $*$ & $*$ & $*$ & $*$ & $*$ & $*$ & $*$ & $*$ & $*$ & $\mathrm{~T}$ & & 2 & & 2 \\
\hline TG5 & $*$ & A & $*$ & $*$ & G & * & * & * & * & * & $*$ & G & $*$ & * & * & * & 2 & 2 & & 4 \\
\hline TG6 & $*$ & A & $*$ & $*$ & G & * & $*$ & * & $*$ & * & $\mathrm{G}$ & $*$ & $*$ & $*$ & $*$ & * & 3 & & 3 & 6 \\
\hline TG7 & $*$ & $*$ & $*$ & G & $*$ & $*$ & $*$ & $*$ & $*$ & $*$ & $*$ & $*$ & $*$ & $*$ & $\mathrm{C}$ & $\mathrm{T}$ & 3 & 3 & & 6 \\
\hline TG8 & $*$ & A & $*$ & * & * & * & * & * & * & $*$ & G & $*$ & $*$ & G & $*$ & * & & & 1 & 1 \\
\hline TG9 & $*$ & $*$ & $*$ & G & $*$ & $*$ & $*$ & $*$ & $*$ & $*$ & G & $*$ & $*$ & $*$ & $*$ & $\mathrm{~T}$ & & & 1 & 1 \\
\hline \multicolumn{17}{|c|}{ Total } & 14 & 10 & 6 & \\
\hline \multicolumn{17}{|c|}{ Nucleotide diversity (Pi) } & 0.008 & 0.008 & 0.007 & \\
\hline \multicolumn{17}{|c|}{ Number of haplotypes (h) } & 5 & 5 & 4 & \\
\hline \multicolumn{17}{|c|}{ Haplotype diversity (Hd) } & 0.813 & 0.867 & 0.800 & \\
\hline \multicolumn{17}{|c|}{ Number of polymorphic sites (s) } & 9 & 7 & 6 & \\
\hline
\end{tabular}

(Note: Sampling stations IDs, PAH = Pahang; TER = Terengganu; SAR = Sarawak; TG1- TG12 represents the observed haplotypes in Tachypleus gigas; '*' represents the polymorphic mismatches in mentioned nucleotide position). 
Table 3. Localities and molecular characters in T. gigas mtDNA AT-rich region

\begin{tabular}{|c|c|c|c|c|c|}
\hline Sampling sites & Number of samples & $(\mathrm{A}+\mathrm{T}) \%$ & $\mathrm{Ti}: \mathrm{Tv}$ & $h \pm \mathrm{SD}$ & $\pi \pm \mathrm{SD}$ \\
\hline Pahang & 14 & 86.0 & $3: 0$ & $0.813 \pm 0.065$ & $0.0084 \pm 0.0012$ \\
\hline Terengganu & 10 & 86.2 & $3: 0$ & $0.867 \pm 0.071$ & $0.0084 \pm 0.0012$ \\
\hline Sarawak & 6 & 85.9 & $2: 0$ & $0.800 \pm 0.172$ & $0.0067 \pm 0.0017$ \\
\hline
\end{tabular}

(Note: Nucleotide content (A+T\%), number of substitutions (Ti, transition: Tv, Transversion), haplotype diversity $(h)$, and nucleotide diversity $(\pi))$.

Table 4. Pair wise $F$-statistic $\left(F_{\mathrm{ST}}\right)$ values of genetic differentiation and migrants per generation $\left(N_{e} m\right)$ values of gene flow among populations. $F_{\mathrm{ST}}$ values are above the diagonal and $N_{e} m$ values are below the diagonal

\begin{tabular}{|c|c|c|c|}
\hline Populations & PAH & TER & SAR \\
\hline PAH & - & $0.038^{\text {ns }}$ & $0.046^{\text {ns }}$ \\
\hline TER & 12.658 & - & $0.265^{\text {ns }}$ \\
\hline SAR & 10.370 & 1.387 & - \\
\hline
\end{tabular}

Note: $*=p<0.05$, ns: not significant.

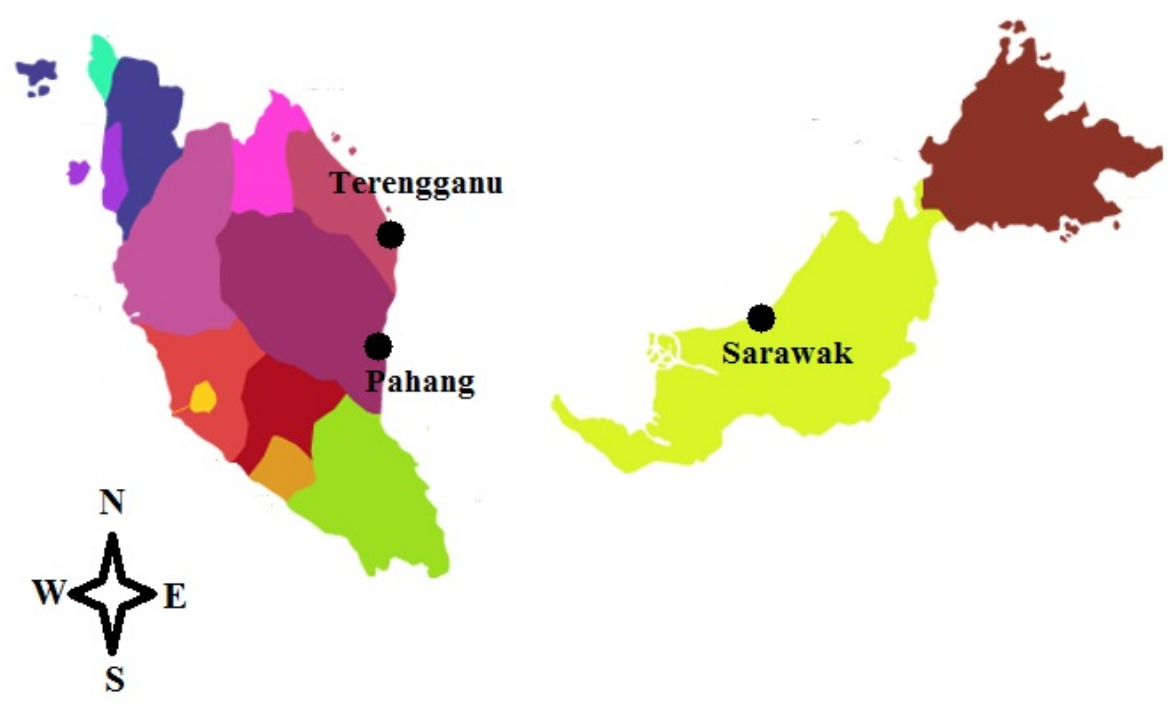

Figure 1. Location of the sampling area 


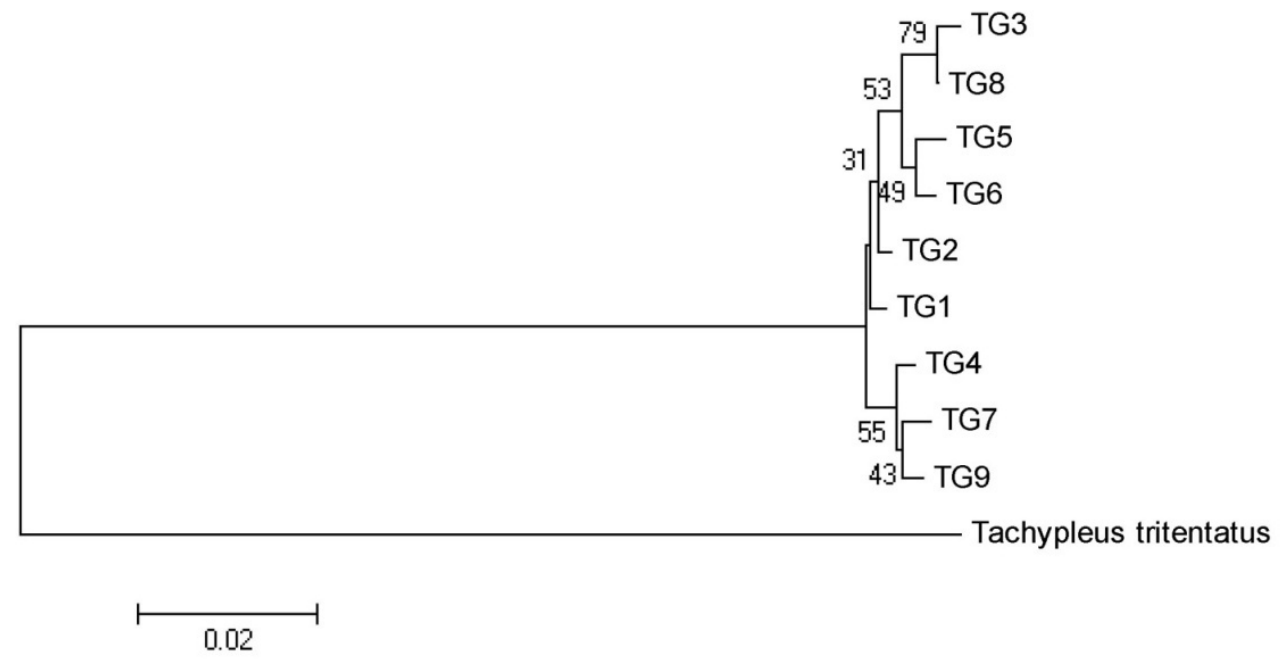

Figure 2. Neighbor-joining (NJ) phylogram showing the relationship among haplotypes of $T$. gigas

The numbers at each node represents the bootstrap percentage values based on 1000 pseudo replications for $\mathrm{NJ} / \mathrm{MP}$ analyses. T. tridentatus used as an out group was clearly clustered in separate branch proves the reliability of the constructed phylogram. 